\title{
Quantitation of hepatitis C viral RNA in liver and serum samples using competitive polymerase chain reaction
}

Faculty of Medicine, Kobe University, Kobe,

Japan:

2nd Department of Internal Medicine

M Sugano

$S$ Yoon

M Kasuga

1st Department of

Pathology

Y Hayashi

T Ninomiya

K Ohta

$\mathrm{H}$ Itoh

Diagnostics Division, Otsuka

Pharmaceutical

Co Ltd.

Japan

M Kinoshita

Correspondence to: Dr Yoshitake Hayashi, 1st Dept of Pathology, Faculty of Medicine, Kobe University,

7-5-1 Kusunoki-cho,

Chuo-ku, Kobe 650,

Japan.

Accepted for publication 18 January 1995

\author{
M Sugano, Y Hayashi, S Yoon, M Kinoshita, T Ninomiya, K Ohta, H Itoh, \\ M Kasuga
}

\begin{abstract}
Aims-To investigate whether the amount of hepatitis C viral RNA (HCV-RNA) in liver and serum can predict the effectiveness of interferon treatment in patients with chronic hepatitis $\mathbf{C}$.

Methods-The amount of HCV-RNA in frozen liver tissues and sera of 22 patients with chronic hepatitis $\mathbf{C}$ was determined before and after interferon alfa treatment by the competitive reverse transcriptional polymerase chain reaction method.

Results-Patients with small amounts of HCV-RNA in serum before treatment showed a significantly more effective response to interferon treatment. After treatment, HCV-RNA disappeared from both the liver and serum of all patients who sustained complete response $(n=11)$; in contrast, HCV-RNA decreased but persisted in the liver of all those who relapsed after cessation of treatment $(n=11)$.

Conclusions-The elimination of hepatitis $C$ virus from the liver as well as from the serum seems to be essential for sustained remission. The quantitation of HCV-RNA in liver biopsy specimens obtained after treatment would be a highly accurate predictor of whether relapse is likely to occur. ( 7 Clin Pathol 1995;48:820-825)
\end{abstract}

Keywords: Hepatitis C, interferon treatment, competitive RT-PCR, liver tissue, liver biopsy, pathology.

Interferon alfa has been used as an effective treatment for chronic hepatitis $\mathrm{C}$ and has been shown to normalise aminotransferase levels. Although approximately $80 \%$ of patients respond to this treatment, half of them suffer later relapse. ${ }^{12}$ The mechanisms of relapse after withdrawal of interferon have not been clarified. The current antibody test has no clinical value in predicting relapse or in monitoring the effects of treatment. ${ }^{3-10}$ Recently a new approach, the genetic amplification method of polymerase chain reaction (PCR), has been applied successfully for the detection of hepatitis C viral RNA (HCV-RNA) in serum, and has provided new insights into the potential mechanisms involved in its pathogenesis. Shindo $e t a l^{11}$ have shown disappearance of $\mathrm{HCV}$ RNA from the serum of the majority $(81 \%)$ of patients responding to a 6 month course of interferon alfa; all respondents also showed a decrease in HCV-RNA levels. ${ }^{11}$ The dis- appearance of HCV-RNA from serum, however, is not predictive of a sustained response to interferon. ${ }^{1212-14}$ Our findings showed that half of those who responded (negative HCVRNA in serum at the end of therapy) later relapsed, with the reappearance of HCV-RNA in serum. These findings suggest that hepatitis $C$ virus was reduced to undetectable level in the serum but was only suppressed in the liver of patients who relapsed after treatment.

To evaluate the antiviral effect of interferon on hepatitis $C$ virus, we determined the amount of HCV-RNA in both the liver and serum of chronic hepatitis $\mathrm{C}$ patients who responded to interferon alfa. A highly sensitive quantitative assay by the competitive reverse transcriptional polymerase chain reaction (RT-PCR) procedure was used. ${ }^{1516}$ The amount of HCVRNA was measured in both the liver tissues and sera obtained before and after treatment, and the results of paired samples were analysed.

\section{Methods}

\section{MATERIALS}

The 22 cases investigated were selected from 72 Japanese patients with chronic hepatitis C referred to our hospital for interferon treatment. All patients had abnormal serum alanine aminotransferase (ALT) and were positive for antibodies to hepatitis $\mathrm{C}$ virus, determined by second generation enzymed linked immunosorbent assay (Ortho), and for serum HCV-RNA, determined by the RT-PCR assay. Before treatment, diagnosis of the biopsy sample in each case confirmed chronic aggressive hepatitis. The patients underwent a 6 month course of treatment with recombinant interferon alfa (9-10 million units (MU) intramuscularly daily for 2-6 weeks and three times weekly thereafter), or with natural interferon alfa (6 MU intramuscularly daily for 2 weeks and three times weekly thereafter).

Of the 72 patients, $56(77 \cdot 8 \%)$ responded with normal ALT levels and disappearance of HCV-RNA from serum at the end of the treatment, and 16 patients $(22.2 \%)$ did not respond. Twenty three of the 56 patients who showed a 6 month sustained normalisation of ALT without serum HCV-RNA after interferon withdrawal are referred to as long term complete responders; 33 patients who relapsed, with an abnormal increase of ALT and reappearance of HCV-RNA within 6 months of interferon withdrawal, are referred to as short term complete responders. 
Mixture of HCV-RNA in sample and different amounts of mutant HCV-RNA

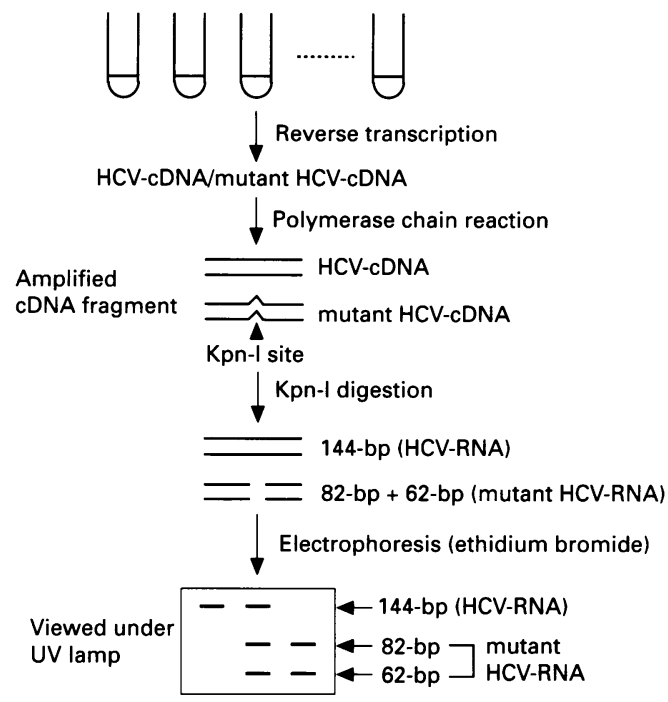

Figure 1 Outline of quantitative assay of hepatitis $C$ virus (HCV) RNA by a competitive reverse transcriptasepolymerase chain reaction method. Different amounts of synthetic mutant $H C V-R N A$ and target $H C V-R N A$ in serum (or liver) samples were amplified in the same tube. After digestion with Kpn-I and electrophoresis on an agarose gel, amplified DNA fragments were separated into three bands and viewed under an ultraviolet lamp.

Paired biopsied specimens of liver and serum samples were obtained twice, before and after interferon treatment, from 22 patients: 11 long term responders and 11 short term responders. Each liver sample was divided into two fragments: a larger one was embedded in paraffin and stained for histological diagnosis, and the other, about $2-5 \mathrm{~mm}$ in length, was snap frozen and stored at $-80^{\circ} \mathrm{C}$ for assay by competitive RT-PCR. Histological diagnoses were performed by routine microscopic examination of the sections stained with a haematoxylin-eosin, and where necessary, with Masson's trichrome. Biopsy specimens were evaluated as showing chronic persistent hepatitis $(\mathrm{CPH})$, moderate chronic aggressive hepatitis (CAH2A), severe chronic aggressive hepatitis (CAH2B), or cirrhosis (LC), ${ }^{17}$ and graded according to the histological activity index for numerical scoring of Knodell et al. ${ }^{18}$ Serum materials were also frozen and stocked for measuring HCV-RNA by competitive RT-PCR.
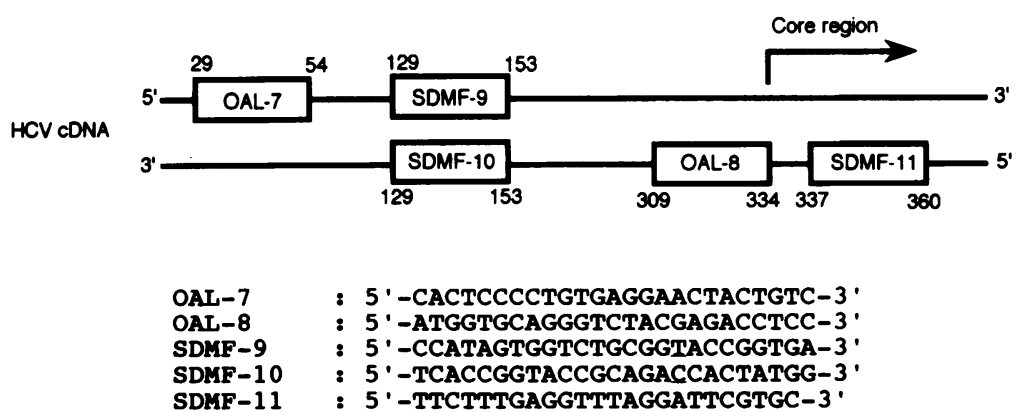

Figure 2 Nucleotide sequences and positions of wild-type (OAL-7, 8, SMDF-11) and mutant-type primers (SDMF-9, 10). A mutant fragment with a restriction enzyme (Kpn-I) digestive site at nucleotide number 145, referred to as TAM 15, was amplified by $P C R$ with $O A L-7$ and $O A L-8$; templating $H C V-c D N A$ was prepared by priming with SDMF-11.
QUANTIFICATION OF HCV-RNA

The RT-PCR assay, as described ${ }^{19}$ with minor modifications, was done first to detect HCVRNA in the serum of all 72 patients before treatment. HCV-RNA was quantified by the competitive RT-PCR assay according to the methods of Becker-Andre and Hahlbrock ${ }^{20}$ or of Hagiwara et al, ${ }^{2}$ with minor modifications, using synthetic mutant HCV-RNA which was synthesised from the $5^{\prime}$ non-translating region of HCV-RNA sequences (fig 1).

\section{SITE DIRECTED MUTAGENESIS AND IN VITRO TRANSCRIPTION}

HCV-RNA in patients' serum was reverse transcribed with SDMF-11 primer. Reverse transcription was carried out at $37^{\circ} \mathrm{C}$ for $60 \mathrm{~min}$ in a mixture (final volume $20 \mu \mathrm{l}$ ) containing RNA sample, 5* reaction buffer, $50 \mathrm{mM}$ DTT, $8 \mu \mathrm{l}$ each of dNTP and $20 \mathrm{pmol}$ of primer, $16 \mathrm{U}$ RNase inhibitor (BRL), and $108 \mathrm{U}$ reverse transcriptase from Moloney murine leukaemia virus (MoMLV) reverse transcriptase (BRL). PCR was separately used to amplify a 125 base pair (bp) fragment with OAL-7 and SDMF10 primers and a $206 \mathrm{bp}$ fragment with SDMF9 and OAL- 8 primers. ${ }^{21}$ A mutant strand with a novel restriction endonuclease (Kpn-I) site was generated by annealing the 25-mer mutagenic primers (referred to as SMDF-9 and SDMF-10) followed by extension with Taq DNA polymerase (fig 2). The $306 \mathrm{bp}$ fragment of the mutant cDNA was force-subcloned into pCR 1000 vector (Stratagene) (referred to as pTAM15) and digested with Eco RI and Hind III. The EcoRI-Hind III fragment was subcloned into KS + Blu-script (Stratagene). The plasmid was linearised with Hind III, and served as a template for T7 RNA polymerase to generate sense transcripts. The templates were digested with ribonuclease-free deoxyribonuclease (fig 3). The mutant RNA transcripts were purified by phenol-chloroform extraction and ethanol precipitation. ${ }^{22}$

\section{RNA PREPARATION AND RT-PCR ASSAY}

The snap frozen tissue was weighed, resolved, and mixed with $500 \mu \mathrm{l}$ guanidine solution. After addition of different amounts of mutant HCVRNA and extraction twice with phenol chloroform, 2.5 volumes of absolute ethanol were added to the aqueous phase. The mixture was left at $-80^{\circ} \mathrm{C}$ overnight, after which the RNA was pelleted by centrifugation $(20 \mathrm{~min}$, $\left.18500 \mathrm{~g}^{\circ} \mathrm{C}\right)$. The pellet was washed with $80 \%$ ethanol, dried, and dissolved in $11 \mu \mathrm{l}$ distilled water. The RNA solution was heated at $75^{\circ} \mathrm{C}$ for $5 \mathrm{~min}$ with $20 \mathrm{pmol}$ of antisense primer and cooled at $0^{\circ} \mathrm{C}$. The reverse transcriptase reaction was performed on a final volume $20 \mu \mathrm{l}$ as described above. Serum $(50-100 \mu \mathrm{l})$ was also mixed with $500 \mu \mathrm{l}$ guanidine solution and subjected to the same procedures.

PCR of 35 and 35 cycles was carried out to amplify a $144 \mathrm{bp}$ fragment of the $5^{\prime}$ nontranslating region of HCV-RNA as described. ${ }^{23}$ The amplification profile was as follows: de- 

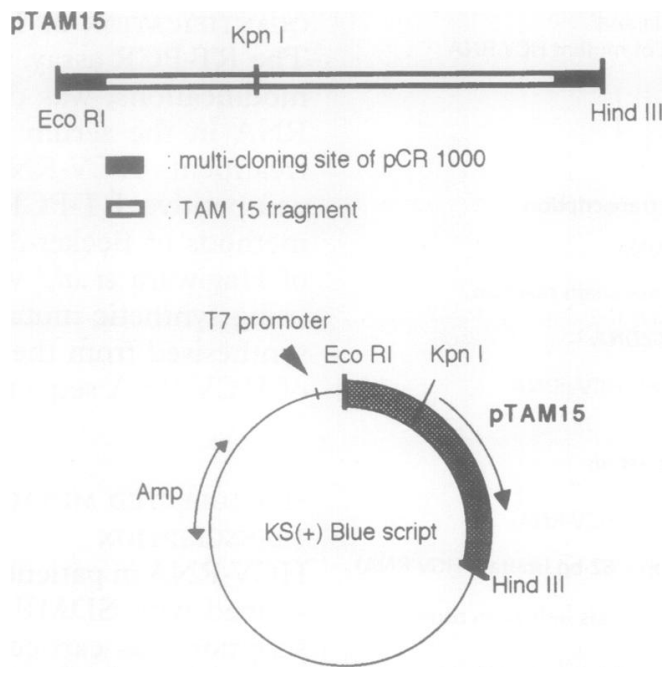

Figure 3 pTAM15 is an EcoRI-Hind III fragment consisting of TAM15 and multicloning site of pCR 1000 at both ends, was inserted into a vector $K S(+)$ Blue script. This plasmid was linearised with Hind III, and served as templates for T7 RNA polymerase to generate sense transcripts.

naturation at $92^{\circ} \mathrm{C}$ for $60 \mathrm{~s}$; annealing at $55^{\circ} \mathrm{C}$ for $45 \mathrm{~s}$; extension at $72^{\circ} \mathrm{C}$ for $120 \mathrm{~s}$. Negative controls (normal liver extracts, no template, or no AMV transcriptase) and positive controls were included in all experiments.

\section{ANALYSIS OF PCR PRODUCTS}

Ten microlitres of each PCR product was treated with $1 \mu \mathrm{l} \mathrm{Kpn-I} \mathrm{(Takara).} \mathrm{After} \mathrm{di-}$ gestion, $10 \mu \mathrm{l}$ of the solution was analysed by electrophoresis on a 3\% agarose gel containing $0.5 \mathrm{mg} / \mathrm{ml}$ ethidium bromide. The gels were viewed and photographed on an ultraviolet transilluminator.

PCR products derived from target $\mathrm{HCV}$ RNA in sera and liver tissues were 144 bp long. Digestion with Kpn-I selectively cuts PCR

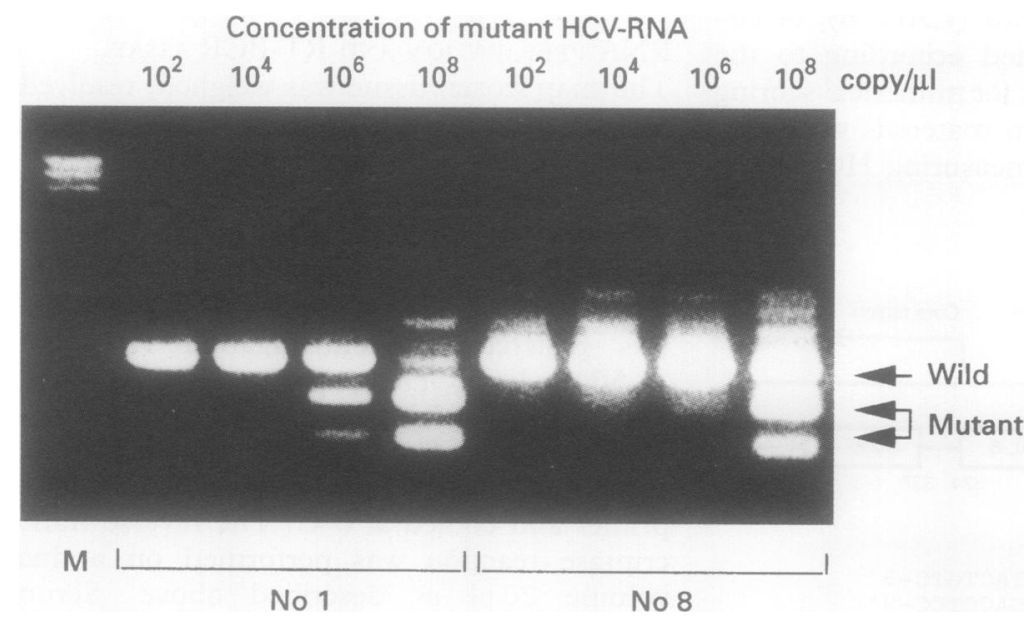

Figure $4 A$ representative result of competitive reverse transcriptase-polymerase chain reaction (RT-PCR) assay. Mixture of $1 \mathrm{mg}$ liver tissue and different amounts of mutated $H C V-R N A$ were tested. After 35 cycles of amplification and Kpn I digestion, the products were analysed by electrophoresis on a 3\% agarose gel. The top band (144-bp) represents amplified DNA fragments derived from target $H C V-R N A$. At the equivalent point of signal intensities between the upper two bands, the amounts of target $H C V-R N A$ are the same as the copy neumbers of the competitor (No $1: 10^{7}=$ copies $/ \mathrm{ml} ;$ No $8: 10^{8}=$ copies/ $\mathrm{ml}$ ). Numbers are the copies of synthetic mutated HCV-RNA.
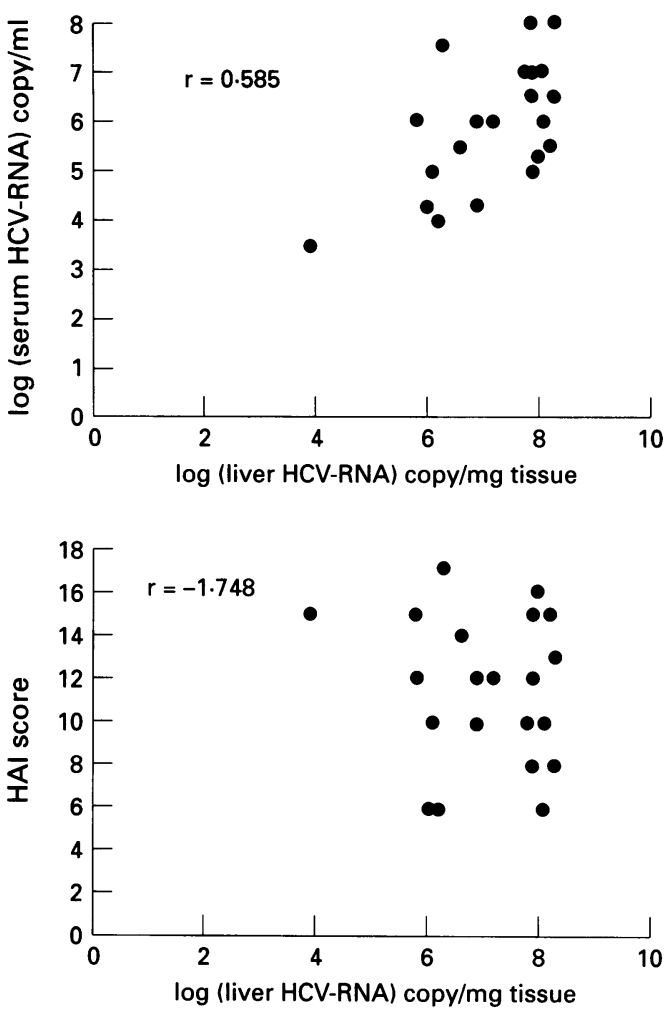

Figure 5 Data are plotted as log (serum HCV-RNA) copy/ml v log (iver HCV-RNA) copy/mg tissue and histological activity index (HAI) score $v$ log (liver HCV$R N A$ ) copy/mg tissue in the 22 patients before interferon treatment. $H C V=$ hepatitis $C$ virus.

products derived from mutant HCV-RNA into two fragments of 82 and 62 bp in length. A representative result of competitive RT-PCR assay is shown in fig 4. The amount of HCVRNA in serum or liver tissue was determined by comparing the signal intensities of the three bands on an agarose gel. Target HCV-RNA of $>10^{2}$ copies were quantified.

\section{Results}

The genomic, histological, and biochemical data of the long term and short term responders are listed in tables 1 and 2, respectively.

\section{ANALYSIS OF QUANTITIES OF HCV-RNA IN SERUM AND LIVER TISSUE}

The amount of HCV-RNA in serum correlated well with that in liver tissue from each patient in the long term and short term responder groups before interferon treatment $(r=0.585$, fig 5), but this correlation disappeared after the treatment, and HCV-RNA persisted only in the liver tissue of the short term responders (table 2). Before interferon treatment, the quantity of HCV-RNA in sera and liver tissue of the long term responders was smaller than that in the short term responders (sera: 5.0 (SD 0.9) and 6.3 (1.1) logarithmic HCV-RNA copy $/ \mathrm{ml}$, respectively; liver tissue: $6.8(1.0)$ and $7.4(1.3)$ logarithmic HCV-RNA copy/mg tissue, respectively), but these differences were statistically not significant (table 1 and table 2 ). However, the majority of the patients with 
Table 1 Serological and histological data for the long term complete responder group

\begin{tabular}{|c|c|c|c|c|c|c|c|c|c|c|}
\hline \multirow{2}{*}{$\begin{array}{l}\text { Case } \\
\text { No }\end{array}$} & \multicolumn{2}{|c|}{$\begin{array}{l}\text { Serum } A L T \\
\text { (IUIl) }\end{array}$} & \multicolumn{2}{|l|}{ Histology } & \multicolumn{2}{|c|}{ HAI scores } & \multicolumn{2}{|c|}{$\begin{array}{l}\text { Serum } H C V-R N A \\
{[\log (\operatorname{cop} y / m l)]}\end{array}$} & \multicolumn{2}{|c|}{$\begin{array}{l}\text { Liver HCV-RNA } \\
\text { [log (copy/mg tissue)] }\end{array}$} \\
\hline & Before & After & Before & After & Before & After & Before & After & Before & After \\
\hline 1 & 77 & 17 & $\mathrm{CAH} 2 \mathrm{~A}$ & $\mathrm{CPH}$ & 6 & 3 & $4 \cdot 0$ & $<2$ & $6 \cdot 2$ & $<2$ \\
\hline 2 & 149 & 17 & CAH2A & CPH & 6 & 6 & $4 \cdot 3$ & $<2$ & 6.0 & $<2$ \\
\hline 3 & 326 & 33 & CAH2A & CAH2A & 10 & 11 & $4 \cdot 3$ & $<2$ & 6.9 & $<2$ \\
\hline 4 & 91 & 25 & CAH $2 A$ & $\mathrm{CAH} 2 \mathrm{~A}$ & 10 & 8 & $5 \cdot 0$ & $<2$ & $6 \cdot 1$ & $<2$ \\
\hline 5 & 85 & 7 & CAH2A & CPH & 12 & 3 & $5 \cdot 0$ & $<2$ & $7 \cdot 9$ & $<2$ \\
\hline 6 & 244 & 33 & CAH2B & CAH2B & 14 & 10 & $5 \cdot 5$ & $<2$ & $6 \cdot 6$ & $<2$ \\
\hline 7 & 191 & 41 & $\mathrm{CAH} 2 \mathrm{~B}+\mathrm{LC}$ & CAH2B & 15 & 10 & $5 \cdot 5$ & $<2$ & $8 \cdot 2$ & $<2$ \\
\hline 8 & 162 & 13 & CAH2A & CPH & 12 & 7 & $6 \cdot 0$ & $<2$ & $5 \cdot 8$ & $<2$ \\
\hline 9 & 156 & 22 & CAH2B & CAH2B & 15 & 8 & $6 \cdot 0$ & $<2$ & $5 \cdot 8$ & $<2$ \\
\hline 10 & 118 & 38 & CAH2B & CAH2B & 12 & 10 & $6 \cdot 0$ & $<2$ & $7 \cdot 2$ & $<2$ \\
\hline 11 & 468 & 20 & CAH2B & CAH2A & 13 & 6 & $6 \cdot 5$ & $<2$ & $8 \cdot 3$ & $<2$ \\
\hline
\end{tabular}

ALT = alanine transaminase; $\mathrm{HAI}=$ histological activity index; $\mathrm{HCV}=$ hepatitis $\mathrm{C}$ virus; $\mathrm{CPH}=$ chronic persistent hepatitis; $\mathrm{CAH} 2 \mathrm{~A}=$ moderate chronic aggressive hepatitis; $\mathrm{CAH} 2 \mathrm{~B}=$ severe chronic aggressive hepatitis; CAH $2 \mathrm{~B}+\mathrm{LC}=\mathrm{severe}$ chronic aggressive hepatitis with cirrhosis.

Table 2 Serological and histological data for the short term complete responder group

\begin{tabular}{|c|c|c|c|c|c|c|c|c|c|c|}
\hline \multirow{2}{*}{$\begin{array}{l}\text { Case } \\
\text { No }\end{array}$} & \multicolumn{2}{|c|}{$\begin{array}{l}\text { Serum } A L T \\
\text { level (IU/l) }\end{array}$} & \multicolumn{2}{|l|}{ Histology } & \multicolumn{2}{|c|}{ HAI scones } & \multicolumn{2}{|c|}{$\begin{array}{l}\text { Serum } H C V-R N A \\
{[\log (\text { copylml)] }}\end{array}$} & \multicolumn{2}{|c|}{$\begin{array}{l}\text { Liver HCV-RNA } \\
\text { [log (copy/mg)] }\end{array}$} \\
\hline & Before & After & Before & After & Before & After & Before & After & Before & After \\
\hline $\begin{array}{l}12 \\
13 \\
14 \\
15 \\
16 \\
17 \\
18 \\
19 \\
20 \\
21 \\
22\end{array}$ & $\begin{array}{r}141 \\
96 \\
148 \\
52 \\
137 \\
100 \\
24 \\
43 \\
350 \\
111 \\
63\end{array}$ & $\begin{array}{r}221 \\
15 \\
16 \\
23 \\
95 \\
16 \\
8 \\
12 \\
43 \\
19 \\
12\end{array}$ & $\begin{array}{l}\text { CAH2B } \\
\text { CAH2B + LC } \\
\text { CAH2A } \\
\text { CAH2A } \\
\text { CAH2B } \\
\text { CAH2A } \\
\text { CAH2A } \\
\text { CAH2A } \\
\text { CAH2B + LC } \\
\text { CAH2A } \\
\text { CAH2A }\end{array}$ & $\begin{array}{l}\text { CAH2B } \\
\text { CAH2B + LC } \\
\text { CAH2A } \\
\text { CPH } \\
\text { CAH2A } \\
\text { CPH } \\
\text { CAH2A } \\
\text { CAH2A } \\
\text { CAH2B + LC } \\
\text { normal liver } \\
\text { CAH2A }\end{array}$ & $\begin{array}{r}15 \\
16 \\
12 \\
6 \\
15 \\
10 \\
8 \\
8 \\
10 \\
17 \\
8 \\
8\end{array}$ & $\begin{array}{r}15 \\
15 \\
10 \\
5 \\
10 \\
4 \\
8 \\
4 \\
15 \\
2 \\
6\end{array}$ & $\begin{array}{l}3 \cdot 5 \\
5 \cdot 3 \\
6 \cdot 0 \\
6 \cdot 0 \\
6 \cdot 5 \\
7 \cdot 0 \\
7 \cdot 0 \\
7 \cdot 0 \\
7 \cdot 5 \\
8 \cdot 0 \\
8 \cdot 0\end{array}$ & $\begin{array}{l}<2 \\
<2 \\
<2 \\
<2 \\
<2 \\
<2 \\
<2 \\
<2 \\
<2 \\
<2 \\
<2\end{array}$ & $\begin{array}{l}3 \cdot 9 \\
8 \cdot 0 \\
6 \cdot 9 \\
8 \cdot 1 \\
7 \cdot 9 \\
7 \cdot 8 \\
7 \cdot 9 \\
8 \cdot 1 \\
6 \cdot 3 \\
7 \cdot 9 \\
8 \cdot 3\end{array}$ & $\begin{array}{l}2 \cdot 3 \\
2 \cdot 0 \\
4 \cdot 0 \\
7 \cdot 1 \\
5 \cdot 0 \\
2 \cdot 2 \\
4 \cdot 1 \\
6 \cdot 3 \\
5 \cdot 8 \\
4 \cdot 2 \\
6 \cdot 9\end{array}$ \\
\hline
\end{tabular}

$\mathrm{ALT}=$ alanine transaminase; $\mathrm{HAI}=$ histological activity index; $\mathrm{HCV}=$ hepatitis $\mathrm{C}$ virus; $\mathrm{CPH}=$ chronic persistant hepatitis; $\mathrm{CAH} 2 \mathrm{~A}=$ moderate chronic aggressive hepatitis; $\mathrm{CAH} 2 \mathrm{~B}=$ severe chronic agreesive hepatitis; CAH2B $+\mathrm{LC}=$ severe chronic aggressive hepatitis with cirrhosis.

serum HCV-RNA under $10^{6}$ copies/ml were long term responders $(10 / 14 ; 71 \cdot 4 \%)$, whereas most of the patients with serum HCV-RNA over $10^{6}$ copies $/ \mathrm{ml}$ were short term responders $(7 / 8,87.5 \%) ; 7 / 10$ patients with liver $\mathrm{HCV}$ RNA under $10^{7}$ copies/mg tissues were long term responders $(70 \%)$, and $8 / 12$ patients with liver HCV-RNA over $10^{7}$ copies/mg tissue were short term responders $(66 \cdot 7 \%)$. Treatment was significantly more effective in patients with serum HCV-RNA under $10^{6}$ copies $/ \mathrm{ml}$ ( $p<0.05$, by Fisher's test).

After treatment, HCV-RNA was not detected in the sera of either group, signifying that interferon had eliminated it from the serum. In the liver tissue, HCV-RNA was not detected in
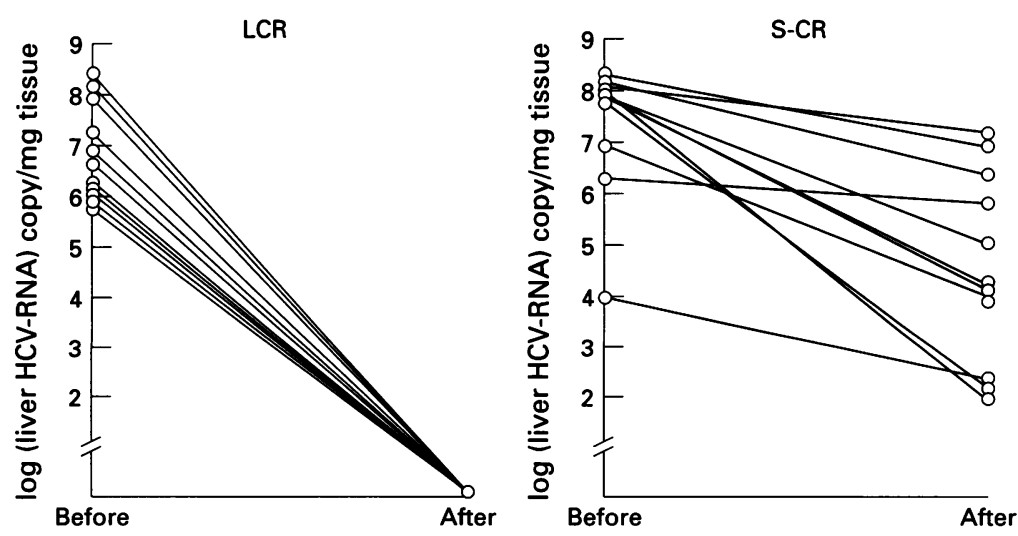

Figure 6 Quantitation of HCV-RNA in liver tissue in long term (LCR) and short term (SCR) complete responder groups before and after interferon treatment. HCV $=$ hepatitis $C$ virus. the long term responders (table 1); in contrast, HCV-RNA decreased but persisted in the short term responders $(4.8$ (1.9) logarithmic HCVRNA copy/mg tissue) (table 2). The amount of HCV-RNA in liver tissue of the two groups before and after treatment is shown in fig 6 .

\section{ANALYSIS OF HISTOLOGICAL ACTIVITY INDEX SCORE}

Histological damage was estimated by the histological activity index score (for each of the following factors: (1) periportal and/or bridging necrosis; (2) intralobular degeneration and focal necrosis; (3) portal inflammation; (4) fibrosis of liver tissue) before and after interferon treatment. Before treatment, the difference in scores between the long term responders and the short term responders was not significant, at $11.0(3.2) v 10.8(3.5)$. There was no correlation between the points of the histological activity index score and the amount of HCVRNA in liver tissue (fig 5). Interferon treatment had more effect in the long term responders than in the short term responders on the index score at the end of treatment (7.3 (3.7) $v 9.6$ $(4 \cdot 6)$, but the difference was not statistically significant (tables 1 and 2).

\section{Discussion}

Interferon alfa is useful in eliminating HCVRNA from patients with chronic hepatitis C; however, relapse occurs in many cases. Some seem to have only a transient flare in aminotransferase activity, but in the majority, hepatitis 
recurs with persistent biochemical abnormality. Recently the RT-PCR assay for the detection of HCV-RNA has shown that a relapse of hepatitis is always accompanied by the appearance of HCV-RNA in serum, indicating transient suppression of viral replication. ${ }^{1323}$ In our study of the 72 patients who underwent a 6 month course of interferon treatment, 56 $(77 \cdot 8 \%)$ showed disappearance of HCV-RNA from the serum at the end of treatment, 23 $(31.9 \%)$ showed continued normalisation of aminotransferase levels and HCV-RNA-free serum after treatment, and $33(45 \cdot 8 \%)$ relapsed, with the reappearance of HCV-RNA in serum within 6 months. The treatment in the relapsed patients may only have produced a decrease in the amount or virus or an inhibition of viral replication, ${ }^{21114}$ indicating that the virus was not eradicated from the liver, one of its major reservoirs. Although HCV-RNA was not detected in serum after the 6 month course of interferon, whether or not it was eliminated and whether or not treatment should be prolonged remained unresolved. We therefore investigated the quantification of HCV-RNA in serum and liver by competitive RT-PCR assay to evaluate the antiviral effect of interferon and to gauge whether such quantification serves as a predictor of sustained response.

In this study, we have shown that before treatment the amount of HCV-RNA in serum correlated well with that in the liver in all patients. After treatment, HCV-RNA disappeared from the liver and serum of the long term responders, while in the short term responders it decreased but persisted at a lower level in the liver. These results indicate that sustained response after interferon withdrawal (long term responder group) is associated with complete elimination of the virus from the liver-or at least with a decrease in the virus load to levels below those measured with our competitive RT-PCR method-and also that the liver is a possible major reservoir for the hepatitis $\mathrm{C}$ virus. In this respect, Balart et al reported that biochemical relapse occurred in four of 11 "responding" patients in whom disappearance of HCV-RNA from liver tissues was shown by current RT-PCR methods, but that this disappearance could not be used to predict sustained remission. They suggested several possible explanations for this phenomenon: (1) sampling variations, or too small a biopsy sample to evaluate the amount of virus; (2) failure of their PCR method to detect minute amounts of virus in liver tissues; (3) other organs or tissues acting as reservoirs for the virus. ${ }^{1}$ In relation to this last possibility, Gil et $a l^{12}$ suggested that a relapsed patient without $\mathrm{HCV}$ in the liver and serum after interferon treatment had positive strand HCV-RNA in peripheral blood mononuclear cells, which suggests that replication of hepatitis $C$ virus may be occurring in these cells. In our study of a larger number of consecutive cases, all relapsed patients with HCV-RNA in liver tissue were from the short term responder group, and those without HCV-RNA in serum and liver were long term responders. This discrepancy between our findings and those of Gil remains unresolved, but we consider that the relapsed patients without HCV-RNA in sera and liver tissues are the exception and that our competitive RT-PCR method is more sensitive for detecting HCV-RNA in liver biopsy specimens.

In our studies and those of others, ${ }^{101213}$ the disappearance of HCV-RNA from sera after interferon treatment was not an accurate gauge of its complete elimination. Although prolonged treatment with interferon alfa seems necessary for sustained remission, ${ }^{2425}$ factors predicting a beneficial response have remained unclear. For establishing an effective schedule of treatment, it is necessary to make a clear and early identification of factors affecting individual sensitivity to interferon. In the samples before treatment, the quantity of HCV-RNA in both serum and liver of the long term responders was smaller than in the short term responders, and in particular most of the cases with under $10^{6}$ copies $/ \mathrm{ml}$ of HCV-RNA in serum were long term responders. This suggests that interferon treatment is likely to be more effective in patients with a smaller amount of HCV-RNA as measured by our competitive PCR method. To evaluate whether histology could predict individual sensitivity to interferon, we applied the histological activity index scoring system to estimate the histological changes in liver biopsy specimens before and after treatment, and found that the scores before treatment could not predict effectiveness, but that after treatment histological damage was less pronounced in the longer term responders.

We have shown in this study that interferon treatment has a strong antiviral effect which eliminates HCV-RNA from the sera of the majority of patients and promotes sustained complete remission when the virus is also eliminated from the liver; relapse occurs, however, when HCV-RNA in serum quantitated by our competitive RT-PCR method appears to have a significant correlation with the response to interferon in most patients. The quantitation of HCV-RNA, particularly in liver biopsy specimens obtained after treatment, would therefore be a highly accurate predictor of whether or not the patient is likely to relapse.

This work was supported in part by a Grant in Aid for Scientific Research (C 05807014) from the Ministry of Education, Science and Culture, Japan. We are grateful to Ms Mari Kohmoto for technical assistance with competitive PCR assays.

1 Balart LA, Perrillo R, Roddenberry J, Regenstein F, Shim $\mathrm{K}-\mathrm{S}$, Shieh YSC, et al. Hepatitis C RNA in liver of chronic hepatitis $\mathrm{C}$ patients before and after interferon chronic hepatitis C patients before and after interf

2 Hagiwara H, Hayashi N, Mita E, Takehara T, Kasahara A, Fusamoto $\mathrm{H}$, et al. Quantitative analysis of hepatitis C
and Fusamoto $\mathrm{H}$, et al. Quantitative analysis of hepatitis C
virus RNA in serum during interferon alfa therapy. Gastrovirus RNA in serum during inter
enterology 1993;104:877-83.

3 Kuo G, Choo QL, Alter HJ, Gitnick GL, Redeker AG, Purcell RH, et al. An assay for circulating antibodies to a major etiologic virus of human non-A, non-B hepatitis. Science 1989;244:362-4.

4 McGuinness PH, Bishop GA, Lien A, Wiley B, Parsons C, McCaughan GW. Detection of serum hepatitis $C$ virus RNA in HCV antibody-seropositive volunteer blood donors. Hepatology 1993;18:485-90.

5 Chaudhary RK, Maclean C. Detection of antibody to hepatitis $\mathrm{C}$ virus by second-generation enzyme immunoassay. 7 Clin Pathol 1993;99:702-4.

6 Hagiwara H, Hayashi N, Mita E, Hiramatsu N, Ueda K, Takehara T, et al. Detection of hepatitis C virus RNA in serum in chronic liver disease. Acta Hepatol fpn 1991;32: $762-6$. 
7 Nalpas B, Thiers V, Pol S, Driss F, Thepot V, Berthelot P, et al. Hepatitis C viremia and anti-HCV antibodies in alcoholics. f Hepatol 1992;14:381-4.

8 Sakamoto N, Sato C, Haritani H, Mackawa S, Kurosak $M$, Enomoto N, et al. Detection of hepatitis C viral RNA in sporadic acute non-A, non-B hepatitis by polymerase chain reaction. $\mathcal{F}$ Hepatol $1993 ; 17: 28-33$.

9 Yuki N, Hayashi N, Hagiwara H, Takehara T, Oshita M, Yuki $\mathrm{N}$, Hayashi $\mathrm{N}$, Hagiwara $\mathrm{H}$, Takehara T, Oshita M, Kasahara A, et al. Serodiagnosis of chronic hepatitis C in Japan by second-generation

10 Yuki N, Hayashi N, Hagiwara H, Takahara T, Katayama $\mathrm{K}$, Kasahara A, et al. Quantitive analysis of antibodies to hepatitis $C$ virus during interferon $-\alpha$ therapy. Hepatology 1993;17:960-5.

11 Shindo M, Di Bisceglie AM, Cheung L, Shih JW-K, Cristiano K, Feinstone SM, et al. Decrease in serum hepatitis $C$ viral RNA during alpha-interferon therapy for chronic hepatitis C. Ann Intern Med 1991;115:700-4.

12 Gil B, Qian C, Riezu-Boj JI, Civeira MP, Prieto J. Hepatic and extrahepatic HCV RNA strands in chronic hepatitis C: different patterns of response to interferon treatment. Hepatology 1993;18:1050-4.

13 Hagiwara H, Hayashi N, Mita E, Ueda K, Takehara T, Kasahara A, et al. Detection of hepatitis $C$ virus RNA in Kasahara A, et al. Detection of hepatitis C virus RNA in
serum of patients with chronic hepatitis $C$ treated with interferon- $\alpha$. Hepatology 1992;15:37-41.

14 Kakumu S, Yoshioka K, Wakita T, Ishikawa T, Takayanag M, Higashi Y. A pilot study of Ribavirin and interferon beta for the treatment of chronic hepatitis C. Gastroenterology 1993;105:507-12.

15 Gilliland G, Perrin S, Blanchard K, Bunn HF. Analysis of cytokine mRNA and DNA: detection and quantitation by competitive polymerase chain reaction. Proc Natl Acad Sci $U S A$ 1990;87:2725-9.

16 Kato N, Yokosuka O, Hosoda K, Ito Y, Ohto M, Omata
M. Quantification of hepatitis C virus by competitive reverse transcription-polymerase chain reaction: increase of the virus in advanced liver disease. Hepatology 1993; 18:16-20.

17 De Groote J, Desmet VJ, Gedigk P, Korb G, Popper H, Poulsen $\mathrm{H}$, et al. A classification of chronic hepatitis. Lancet 1968;i:626-8.

18 Knodell RG, Ishak KG, Black WC, Chen TS, Graig R Kaplowitz N, et al. Formulation and application of a numerical scoring system for assessing histological activity in asymptomatic chronic active hepatitis. Hepatology 1981 ; in asymptom.

19 Ito W, Ishiguro H, Kurosawa Y. A general method for introducing a series of mutations into cloned DNA using the polymerase chain reaction. Gene 1991;102:67-70.

20 Becker-André $M$, Hahlbrock $K$. Absolute mRNA quantification using the polymerase chain reaction (PCR). A novel approach by a PCR aided transcript titration assay (PATTY). Nucleic Acids Res 1989;17:9437-46.

21 Kinoshita $M$, Shin S, Aono T. A sensitive and quantitative method for the determination of number of HPV 16 DNA copies by using the competitive polymerase chain reaction. copies by using the competitive polymerase
Genet Anal Tech Appl 1993;10:116-21.

22 Okamoto T, Yoshizawa H, et al. The 5'-terminal sequence of the T, Yoshizawa H, et al. The 5'-terminal sequence of the 23 Shindo M, Di Bisceglie AM, Hoofnagle JH. Long-term follow-up of patients with chronic hepatitis $C$ treated with $\alpha$-interferon. Hepatology 1992;15:1013-6.

24 Picciotto A, Varagona G, Valle F, Coviello DA, Lapertos G, Celle G. Interferon therapy in chronic hepatitis C. Evaluation of a low dose maintenance schedule in responder patients. F Hepatol 1993;17:359-63.

25 Iino S, Hino K, Kuroki T, Suzuki H, Yamamoto S. Treatment of chronic hepatitis $C$ with high-dose interferon $\alpha$ 2b. A multicenter study. Dig Dis Sci 1993;38:612-28. 